This article has been published in a revised form in Journal of Southeast Asian Studies, 47 (3). pp. 366-392. https://doi.org/10.1017/S0022463416000242

This version is published under a Creative Commons CC-BY-NC-ND. No commercial re-distribution or re-use allowed. Derivative works cannot be distributed. (C) The National University of Singapore 2016

\title{
The case for proto-Dvāravatī: A review of the art historical and archaeological evidence
}

Stephen A. Murphy

The mid-first millennium CE represents a crucial period in the emergence of early polities in Southeast Asia. However, disagreement remains between archaeologists and art historians as to the precise dating of this shift from prehistory to history. This article focuses on the Dvāravatī period and re-evaluates evidence in Thai and Western language publications. A growing number of sites excavated over the past two decades in particular show occupation from c. the fourth to fifth century onwards while others provide a continual sequence stretching back well into the Iron Age. I argue that evidence from these sites makes a strong case for postulating a protoDvāravatī period spanning $\mathrm{c}$. the fourth to fifth centuries. In doing so this article proposes this period as the timeframe within which the nascent traits and characteristics of what becomes Dväravati in the seventh to ninth centuries are present and gradually developing.

The transition from prehistory to history in Mainland Southeast Asia has been a central issue of scholarship ever since the first attempts to explain the origins of its "classical states' over a century ago. Ideas based around the 'Indianisation' paradigm saw this transition as happening over a short period of time based almost exclusively on external influences. However, today scholarship has reached a more nuanced understanding of this process and sees it as encompassing an interplay between both internal and external factors. Despite this, considerable debate still revolves around the precise nature and timing of the specific transitions in the various regions and cultures. This article focuses on the emergence of the 
Dvāravatī polity/culture in central Thailand, reviewing the evidence to propose a transition period between the fourth to fifth centuries in particular.

The periodisation of time is essentially the default modus operandi of scholars of archaeology, history and art history. There is an overriding tendency to fit events, artefacts, monuments, and so forth into neat historical and chronological boxes. In doing so we feel we gain a clearer understanding of our past, but what happens when an object, a work of art or a culture in question will not fit into one of our prescribed boxes or the hard breaks defined by previous scholarship? The temptation can be to shoehorn the evidence and interpretations to fit within the accepted norms and understandings of a particular culture or tradition.

However, it is in the transitions between periods and epochs that we can observe some of the most telling changes, transformations or in some cases, revolutions. It is to these liminal periods, the grey zones between perceived fixed points, that we should focus our attention. Instead of monolithic, unassailable periods, would it not be better to see past cultures and societies as shifting entities in both time and space that are continually overlapping, merging, meshing, clashing or repulsing that which came before, and that which lies ahead?

In Mainland Southeast Asian scholarship, this phenomenon is encapsulated by the concept known as 'Dvāravatî'. The term can be employed to describe a time period, an art style, a material culture and/or a polity or polities in what is today central and northeast Thailand. Considerable disagreement as to which uses are appropriate and even how to define them exists within the literature on the subject (see table 1$).{ }^{1}$ One of the most contentious

Stephen A. Murphy is Curator (Southeast Asia), at the Asian Civilisations Museum, Singapore. Correspondence in connection with this article should be addressed to: stepheninasia@hotmail.com. The author would like to thank Matthew D. Gallon for his critical feedback on the article and assistance in providing illustrations of Dvāravatī pottery 
definitions is the 'Dvāravatī period'. Following art historical parameters this has usually been defined as spanning the sixth to eleventh centuries. ${ }^{2}$ From an archaeological perspective on the other hand, it has been argued that it stretches from $c$. the fourth to eleventh centuries CE. ${ }^{3}$ Alternatively, by adhering exclusively to written evidence, the Dvāravatī period would be restricted to the seventh to ninth centuries. In addition, Dvāravatî’'s relationship to the preceding time period and cultures (viz. the prehistoric period or Iron Age) is also a bone of contention.

types. I would also like to thank Miriam T. Stark and Nicolas Revire for their feedback and comments on earlier drafts of this article.

${ }^{1}$ The varying and at times competing definitions are summed up by Peter Skilling.

'Dvāravatī: Recent revelations and research', in Dedications to Her Royal Highness Princess Galyani Vadhana Krom Luang Naradhiwas Rajanagarindra on her 80th birthday, ed. Chris Baker (Bangkok: Siam Society, 2003), pp. 87-112.

${ }^{2}$ Hiram Woodward, The sacred sculpture of Thailand: The Alexander B. Griswold collection, The Walters Art Gallery (Baltimore: Walters Art Gallery; Bangkok: River Books, 1997), pp. 46-53; Fine Arts Department (FAD), Sinlapa Thawarawadi tonkamnoet phutthasin nai Prathet Thai / Dvaravati art: The early Buddhist art of Thailand (Bangkok: FAD, 2009), pp. 94-101.

${ }^{3}$ Andrew Barram and Ian Glover, 'Re-thinking Dvaravati', in From Homo erectus to the living traditions: Choice of papers from the 11th International Conference of the European Association of Southeast Asian Archaeologists, ed. Jean-Pierre Pautreau et al. (Chiang Mai: Silkworm, 2008), pp. 175-82; H.G. Quaritch Wales, Dvāravatī: The earliest kingdom of Siam (6th to 11th century A.D.) (London: B. Quaritch, 1969), p. 1. 
The first challenge to the conventional dates of the Dvāravatī period was made by Andrew Barram and Ian Glover. ${ }^{4}$ By utilising the very limited radiocarbon dates available on the period obtained from systematic excavations, along with comparisons from neighbouring 'Indianised' cultures, they argued for the existence of a sub-period referred to as early or proto-Dvāravatī. As archaeological research over the past fifty years has significantly increased both within Thailand, Cambodia and Vietnam, and to a lesser extent, Myanmar, it has become increasingly apparent that Indic influences entered the region from the early to mid-first millennium CE onwards. At Angkor Borei in the Mekong Delta for instance, PreAngkorean Khmer culture begins by the fourth to fifth centuries CE at the latest. Evidence from the Vat Komnou cemetery at this site indicates that it was inhabited from c.500 BCE onwards. A characteristic Vat Komnou-style pottery appears from c.200 BCE-300 CE and shares many similarities with Bennett Bronson's Funan-style pottery from Chansen (see discussion below). ${ }^{5}$ Research from Myanmar shows that the Pyu sites of Beikthano and Sri Ksetra were developing significant Buddhist cultures in these centuries also (Stargardt, this

\footnotetext{
${ }^{4}$ Barram and Glover, 'Re-thinking Dvaravati'; Glover published a follow-up article two years later under the title, 'The Dvaravati gap: Linking prehistory and history in early
} Thailand', Bulletin of the Indo-Pacific Prehistory Association (BIPPA) 30 (2010): 79-86. However, apart from some minor additional discussion on Southeast Asian prehistory, this piece adds little to the argument presented in the preceding paper.

${ }^{5}$ Shawn Szejda Fehrenbach, 'Traditions of ceramic technology: An analysis of the assemblages from Angkor Borei, Cambodia' (M.A. thesis, University of Hawai'i, 2009); see also Miriam Stark, 'Pre-Angkorian and Angkorian Cambodia', in Southeast Asia: From prehistory to history, ed. Ian C. Glover and Peter Bellwood (London: RoutledgeCurzon, 2004), p. 99; Bennet Bronson, 'Excavations at Chansen and the cultural chronology of protohistoric Central Thailand' (Ph.D. diss., University of Pennsylvania, 1976). 
vol.). In light of these developments, it behoves us to revisit the dating of the Dvāravatī period as Barram and Glover have suggested.

Perhaps one of the reasons this has not yet been done derives from the scholarly tendency to impose clear cut-offs between 'prehistory' and 'history' or sometimes 'protohistory'. Also differing data sets, dating methods and approaches between archaeologists and art historians can lead to disagreement on this issue. However, this article's review of the available evidence highlights that in order to fully understand transitions within Southeast Asia a more fluid and flexible understanding which incorporates data sets and interpretations from both disciplines is necessary.

A key factor against an earlier dating of Dvāravatī is that the surviving sculptural and epigraphic evidence cannot be placed earlier than the sixth century. However, the sculpture, architecture, and urban planning that characterise Dvāravatī are the end of a long process, not the beginning. It is therefore necessary to posit a period leading up to their appearance within which these skills, technologies and ateliers could develop. While scholarship is now in agreement that the old view of Indianisation is untenable, some of the implications of this position have not been fully thought through. In the old model championed by scholars such as George Coedès and H.G. Quaritch Wales, Buddhism and Brahmanism (and Indian culture in general) arrived wholesale and were quickly imposed on the local populace. ${ }^{6}$ In this scenario there was no need to posit a period of local development. However, in light of new paradigms, the idea that Dvāravatī sculpture, architecture and literacy appeared almost instantaneously out of a 'late prehistoric period' appears problematic. It is much more probable that these traditions developed over time and reached fruition by the sixth to seventh centuries where they only then became detectable in the archaeological and historical record.

${ }^{6}$ George Coedès, The Indianized states of Southeast Asia, ed. Walter F. Vella, trans. Sue B. Cowing (Honolulu: East-West Center Press, 1968), pp. 36-7; Quaritch Wales, Dvāravatī. 
I argue that this period of development is best referred to as a proto-Dvāravatī period and occurred primarily in the fourth to fifth centuries CE. ${ }^{7}$ This term is preferable to the more commonly used 'late prehistory', which still implies societies that have not developed out of Iron Age phases and also 'early Dvāravatî’'. This latter phase suggests that this culture is already fully formed. Proto-Dvāravatī sufficiently indicates the potential transitional nature of the fourth to fifth centuries, and that Dvāravatī has not yet come into existence but the nascent traits and characteristics are present and developing during this period.

Proto-Dvāravatī implies a culture that is not quite an early historic polity, but is more advanced than an Iron Age chiefdom or kinship-based society. Matthew Gallon has argued that the construction of earthworks and Buddhist monuments played crucial roles in the emerging Dvāravatī culture as it fostered a sense of community between non-kinship based groups. It also allowed emerging elites to materialise their authority. ${ }^{8}$ This shift in communal identity would have been a gradual process of cultural transition, while not necessarily reflecting a direct chiefdom-to-statehood trajectory.

This article makes the case for seeing the fourth to fifth centuries in particular as a proto-Dvāravatī period. It first looks at prevailing understandings of the term Dvāravatī in regards to its definitions as a period, an art style, a material culture and a polity (table 1). It then reviews some of the key Dvāravatī sites to indicate that there is compelling evidence to postulate a proto-Dvāravatī period.

\footnotetext{
${ }^{7}$ The use of this term as an alternative label was first suggested by Barram and Glover, 'Rethinking Dvāravatī’, p. 181.

${ }^{8}$ Matthew D. Gallon, 'Ideology, identity and the construction of urban communities: The archaeology of Kamphaeng Saen, Central Thailand (c. fifth to ninth century CE)' (Ph.D. diss., University of Michigan, 2013), pp. 25-6, 187-91.
} 


\section{The term 'Dvāravatī'}

The initial source of the name 'Dvāravatî̀' was found in Chinese annals in the late nineteenth century. ${ }^{9}$ By the mid-twentieth century this was supplemented by the discovery of a number of inscriptions at sites in central Thailand. The Sanskrit term 'Dvāravatî’' literally means 'which has gates', with Phasook Indrawooth, for instance, suggesting that this refers to characteristics of this culture's urban planning. ${ }^{10}$

The first historical evidence for the term appears in the seventh century. Two Chinese monks, Xuanzang and Yijing, both refer to a country in Southeast Asia called Duoluobodi and Duheloubodi respectively. ${ }^{11}$ In the nineteenth century, it was proposed that these toponyms were the transliteration into Chinese of the Sanskrit 'Dvāravatī' ${ }^{12}$ Further evidence from Chinese sources comes from the recording of three diplomatic missions sent by a polity named Dvāravatī to China in 638, 640, and 649 CE. ${ }^{13}$ The Chinese evidence is significant

${ }^{9}$ Robert L. Brown, The Dvāravatī wheels of the law and the Indianization of Southeast Asia (Leiden: Brill, 1996), p. xxii.

${ }^{10}$ Phasook Indrawooth, 'The archaeology of the early Buddhist kingdoms of Thailand', in Glover and Bellwood, Southeast Asia, p. 120.

${ }^{11}$ Brown, The Dvāravatī wheels, p. xxii; Geoff Wade, 'Beyond the southern borders:

Southeast Asia in Chinese texts to the ninth century', in Lost kingdoms: Hindu-Buddhist sculpture of early Southeast Asia, ed. John Guy (New York: Metropolitan Museum of Art; New Haven: Yale University Press, 2014), p. 27.

${ }^{12}$ Si-yu-ki: Buddhist records of the Western world, trans. Samuel Beal (New York: Paragon, 1968); Mémoire composé a l'Époque de la Grande Dynastie T'ang sur les religieux éminents qui allèrent chercher la loi dans les Pays d'Occident par l'Tsing, trans. Édouard Chavannes (Paris: E. Leroux, 1894).

${ }^{13}$ Brown, The Dvāravatī wheels, p. xxiii. 
from two angles. First, the sending of diplomatic embassies to China clearly indicates that at this time there was a political entity that identified itself using the name Dvāravatī and that it was actively seeking 'international' recognition. Second, the presence of Chinese monks in Southeast Asia during the period illustrates that Buddhist pilgrims were actively travelling around the region.

INSERT <Table 1. Dvaravati scholarship: Authors, concepts and major publications>

Archaeological evidence for the term Dvāravatī initially came from the discovery of two silver coins/medallions excavated at Nern Hin near Phra Pathom Chedi, Nakhon Pathom in 1943 (fig. 1). ${ }^{14}$ Each of the coins bears an inscription in Sanskrit in Pallava script that reads 'śrīdvāravatīśvarapunya'. Coedès translated this as 'meritorious act of the King of Dvāravatī' ${ }^{15}$ Since then, several other medallions with inscriptions including the term 'Dvāravatī' have been found at sites throughout central Thailand such as Khu Bua and U Thong (fig. 1). ${ }^{16}$

INSERT < Figure 1: Map of central and northeast Thailand showing the main Dvāravatī sites (๔ Stephen A. Murphy).

\footnotetext{
${ }^{14}$ Jan J. Boeles, 'The king of Sri Dvāravatī and his regalia', Journal of the Siam Society 52, 1 (1964): 101-3.

${ }^{15}$ Ibid.: 102.

${ }^{16}$ Brown, The Dvāravatī wheels, p. xxii.
} 
This led to a consensus among scholars that the Dvāravatī political entity was based in the Chao Phraya Basin of central Thailand with its centre most likely being located at either Nakhon Pathom or U Thong (fig. 1). Excavations and survey work carried out throughout Thailand over the past forty years have led to more robust definitions of what Dvāravatī material culture primarily consists of. Although objects show some degree of variation between sites and regions, their overall similarity allows them to be viewed as a relatively unified material culture tradition. Objects include several distinctive types of earthenware pottery with carinated bowls, high-fired orange ware, line and wave ware, relatively highfired matte-surfaced semi-fine ware bowls, and to a lesser extent kendi, being the most common diagnostic Dvāravatī types (fig. 2). Dvāravatī ceramics incorporate forms and decorative techniques from both local and South Asian traditions and usually consist of openfired earthenware. Cord or mat-wrapped paddle impressions are common, with line and wave incising or carved stamp impressions also recorded at most sites. ${ }^{17}$ There is also a distinctive range of moulded clay tablets/sealings, terracotta oil lamps, glass, stone and gold jewellery and iron tools. ${ }^{18}$ Objects such as large finger-marked bricks, glass, stone and metal jewellery, and silver coins are characteristic of Dvāravatī assemblages, but also occur at contemporaneous sites throughout Southeast Asia.

INSERT < Figure 2: Common diagnostic Dvaravati pottery types excavated at Kamphaeng Saen. Clockwise from bottom left; sherd with line and wave designs; fragment of carinated vessel found in context dating to the 5th-7th century; fragment of a relatively high-fired

\footnotetext{
${ }^{17}$ Bronson, 'Excavations at Chansen'; Phasook Indrawooth, Dachani Phachanadinpao Samai Thawarawadi [Index pottery of the Dvaravati period] (Bangkok: Siam Press, 1985), in Thai, with English summary; Indrawooth, ‘The archaeology’, p. 135.

${ }^{18}$ Indrawooth, 'The archaeology', p. 134.
} 
matte-surfaced semi-fineware bowl found in context dating to the 5th-6th century; cordmarked sherd typical of Dvaravati pottery but also found throughout Southeast Asia during this period; finger/finger nail-impressed sherd; sherd with 'hanging triangles' design (all photographs courtesy of Matthew D. Gallon)

The process of urbanisation has also been studied as an indicator of Dvāravatī culture. Quaritch Wales, for instance, attempted to create a chronology of their evolution over time from more irregular-shaped plans, which he saw as growing out of Iron Age precedents, to more regular plans influenced by incoming Indic ideas of urban planning. ${ }^{19}$ However, Gallon has pointed out that the chronology of these moats is uncertain at most sites. Therefore it is not possible at this point to develop a clear timeline for their development. ${ }^{20}$ Gallon identifies six site types ranging from irregular to rectangular, but does not see a linear development. Instead they coexist and overlap in time. ${ }^{21}$ Most, however, are either semi-rectangular or rectangular in shape, with some such as Si Thep having an extension added at a later point in time. Other consistent features include religious architecture in brick, laterite or a combination of both. Large-scale stupas are present at sites such as Nakhon Pathom and Si Thep while other monastic buildings such as assembly and ordination halls have been identified at Mueang Sema and Mueang Fa Deat. ${ }^{22}$ The presence of these moats and earthen

\footnotetext{
${ }^{19}$ Quaritch Wales, Dvāravatī, pp. 116-17.

${ }^{20}$ Gallon, Ideology, identity, p. 160.

${ }^{21}$ Ibid., p. 163.

${ }^{22}$ For northeast Thailand see, Stephen A. Murphy, 'Buddhism and its relationship to

Dvāravatī period settlement patterns and material culture in northeast Thailand and central
} 
banks, coupled with religious architecture in stone, laterite or brick are therefore taken as key indicators of Dvāravatī culture.

Based on this evidence, archaeologists have identified a central area of Dvāravatī material culture in the Chao Phraya Basin that spread out to encompass the Khorat Plateau of northeast Thailand and to a lesser extent Laos, and peninsular Thailand. ${ }^{23}$ However, differences and similarities in material culture do not always follow linguistic, ethnic, or political boundaries. The extent of the Dvāravatī material culture, like the art style, is generally accepted to be wider than that of the political entity. It is also possible that this distribution reflects areas of influence or indirect control. Moreover, a common material culture does not necessarily imply a common or homogenous ethnic group.

There is considerable disagreement as to the ethnicity of and language(s) spoken by the inhabitants of Dvāravatī. The most favoured theory is that the majority of people in central Thailand, at least, were ethnically Mon and spoke Mon language. Today, they are based primarily in Mon State in Lower Myanmar. However, Gérard Diffloth has argued that the Nyah Kur people, still present to a very limited extent today in central and northeast Thailand, are the direct linguistic descendants of the Mon of the Dvāravatī period. ${ }^{24}$ However, the epigraphic evidence only indicates that Mon was used for religious purposes and the question remains as to whether it was the dominant vernacular language. As Nicolas

Laos ca. sixth-eleventh centuries A.D: A historical ecology approach to the landscape of the Khorat Plateau', Asian Perspectives 52, 2 (2014): 300-326.

${ }^{23}$ For northeast Thailand and Laos, see ibid.

${ }^{24}$ Gérard Diffloth, The Dvāravatī Old-Mon language and Nyah Kur (Bangkok:

Chulalongkorn University Print House, 1984). For a recent challenge to this interpretation see Emmanuel Guillon, 'Mōns anciens-Mōns actuels', in Dvāravatī: aux sources du bouddhisme en Thaïlande, ed. Pierre Baptiste and Thierry Zéphir (Paris: Musée Guimet, 2009), pp. 47-51. 
Revire has pointed out, in central and northeast Thailand, donative/dedicatory inscriptions were written in either Mon or Khmer while citation inscriptions were in Pali or Sanskrit. ${ }^{25}$

\section{The Dvāravatī art style}

The most widely recognised use of the label 'Dvāravatî' is in reference to a style of art and architecture. The concept of a Dvāravatī art style originated in 1926 with the publication of Tamnan phraphuttha chedi by Prince Damrong Rajanubhab as part of his formulation and classification of art styles in Thailand. ${ }^{26}$ This work was later translated into English in an abridged form. ${ }^{27}$ This classification system was espoused by Coedès in his guide to the National Museum Bangkok published two years later. ${ }^{28}$ The way the objects

${ }^{25}$ See Nicolas Revire, 'Glimpses of Buddhist practices and rituals in Dvāravatī and neighbouring cultures', in Before Siam: Essays in art and archaeology, ed. Nicolas Revire and Stephen A. Murphy (Bangkok: River Books; Siam Society, 2014), pp. 249-52.

${ }^{26}$ Prince Damrong Rajanubhab, Tamnan phraphuttha chedi [The chronicles concerning Buddhist pagodas] (Bangkok: Sophon Phiphattanakon, BE 2469 [1926]). This was originally printed for free distribution at his mother's funeral as part of the cremation memorial. See Maurizio Peleggi, 'From Buddhist icons to national antiquities: Cultural nationalism and colonial knowledge in the making of Thailand's history of art', Modern Asian Studies 47, 5 (2013): 1520 .

${ }^{27}$ The translation consists of chapters 8 and 9 of the original work and was published under the title, A history of Buddhist monuments in Siam, trans. Sulak Sivaraksa (Bangkok: Siam Society, 1962); it was republished in a revised translation as Monuments of the Buddha in Siam, trans. Sulak Sivaraksa and A.B. Griswold (Bangkok: Siam Society, 1973; repr. Bangkok: Diskul Foundation, 1982).

${ }^{28}$ George Coedès, Les Collections archéologiques du Musée National de Bangkok, Ars 
were displayed and curated in the museum also followed this classification and by the time the guide was published in 1928 this system had essentially become entrenched in the scholarship of both Thai and international scholarship alike. ${ }^{29}$ The classification of a Dvāravatī art style was further developed by scholars such as Pierre Dupont, M.C. Subhadradis Diskul, ${ }^{30}$ Jean Boisselier and Hiram Woodward, among others. ${ }^{31}$ The only challenge to date of this system has been by the Thai art historian Piriya Krairiksh who argued that the art of Thailand should be classified by regional styles and religious

Asiatica Series, vol. 12 (Paris and Brussels: Van Oest, 1928).

${ }^{29}$ Peleggi argues that this classification system was in fact the result of about ten years of close collaboration between Coedès and Prince Damrong. Peleggi, 'From Buddhist icons to antiquities': 1540 .

${ }^{30}$ The youngest son of Prince Damrong Rajanubhab.

${ }^{31}$ Pierre Dupont, L'archéologie Mône de Dvāravatī, 2 vols. (Paris: EFEO, 1959);

Subhadradis Diskul, 'The development of Dvāravatī sculpture and a recent find from Northeast Thailand', in Early South East Asia: Essays in archaeology, history and historical geography, ed. Ralph B. Smith and William Watson (New York: Oxford University Press, 1979), pp. 360-70; Jean Boisselier, The heritage of Thai sculpture (New York: Weatherhill, 1975); Woodward, Sacred sculpture, pp. 43-74. 
affiliations. ${ }^{32}$ This system is also problematic, however, not least because in many instances it is difficult to ascertain the precise religious affiliation of an artefact or sculpture. ${ }^{33}$

It is with the concept of Dvāravatī art that we encounter a key problem in attempts to define a Dvāravatī period. This concept, is in a sense, a case of academically placing the cart before the horse. Scholars first defined the art style and then extrapolated an historical period from it, as opposed to the other way around. Therefore, from the outset the boundaries of the Dvāravatī period have been set, and essentially restricted by the limits of this art style, even when there has been archaeological evidence suggesting a revision of these dates.

Furthermore, the concept of Dvāravatī has become closely associated, or arguably inseparable, from the emergence of Buddhism, and by extension, Buddhist art in the region. However, there is a need to reassess this association. The emergence of Dvāravatī and the emergence of Buddhism are not one and the same thing. ${ }^{34}$ They are interrelated, however, as shown in the overview of the features of Dvāravatī art below.

In 1939 to 1940 Pierre Dupont and the Fine Arts Department of Thailand (FAD) carried out excavations in Nakhon Pathom. Out of this came the posthumous 1959 publication, L'archéologie mône de Dvāravatī. It discussed the excavations and their results, as well as a detailed analysis of Dvāravatī art. This analysis laid the foundations upon which

\footnotetext{
${ }^{32}$ See Piriya Krairiksh, Art styles in Thailand: A selection from national provincial museums and an essay in conceptualization (Bangkok: Fine Arts Department, 1977); Piriya Krairiksh, The roots of Thai art (Bangkok: River Books, 2012).

${ }^{33}$ In this regard, see Nicolas Revire, 'Book review of The roots of Thai art, by Piriya Krairiksh (English trans. by Narisa Chakrabongse), Bangkok, River Books, 2012', Journal of the Siam Society 101 (2013): 233-42.

${ }^{34}$ Dvāravatī has long been and continues to be almost exclusively associated with Buddhist art. For a critique of this position see Revire, this vol.
} 
all subsequent scholarship on Dvāravatī art was built. Dupont devised a relative chronology from Dvāravatī Buddha images based on criteria such as the evolution of the monastic dress, the lotus pedestal, facial features, the curls of hair, the ushnisha and the appearance of the lotus bud on top of it.

INSERT < Figure 3: Three examples of Dvaravati sculpture. Clockwise from bottom left; bronze Buddha from U Thong National Museum with hands in the double vitarka mudra gesture; Detail of a Buddha image from the National Museum Bangkok showing the characteristic facial features such as the broad face with thick lips and thick heavy hair curls; Buddha from the Phra Pathom Chedi National Museum showing the classic Dvaravati Ushaped robe (photographs by Stephen A. Murphy). >

Some of the most striking characteristics of Dvāravatī sculpture are the posture, the gestures and the drapery (fig. 3). The Buddha's robe is usually depicted in a smooth, highly stylised fashion and has a diaphanous quality to it. It falls in a ' $U$-shaped' design terminating just above the ankles, a characteristic shared with Gupta images of India. The Dvāravatī art style has one unique iconographic expression, that of the double vitarka mudra. While a single vitarka mudra is relatively widespread in Southeast Asian art, it is rare in South Asia. ${ }^{35}$ However, the depiction of a standing Buddha image with both hands raised in this mudra is

${ }^{35}$ See Nicolas Revire, 'New perspectives on the origin and spread of Bhadrasana Buddhas throughout Southeast Asia (7th-8th centuries CE)', in Connecting empires and states: Selected papers from the 13th International Conference of the European Association of Southeast Asian Archaeologists, ed. Mai Lin Tjoa-Bonatz, Andreas Reinecke and Dominik Bonatz, vol. 2 (Singapore: NUS Press, 2012), pp. 127-43. 
one found primarily in Dvāravatī art and then continues to be employed in some examples of Lopburi period art.

INSERT <Figure 4: Three sections of a Dvaravati dharmacakra: Clockwise from bottom left, the socle, the cakra, the stambha (these three objects are from separate dharmacakra and were not found as a set) (photographs by Stephen A. Murphy).

Carved stone dharmacakras (wheels of the law), are another hallmark of Dvāravatī sculpture (fig. 4). They combine the South Asian religious and political symbol of the wheel with locally derived decorative motifs. ${ }^{36}$ These objects are often found associated with square-based brick chedi that bear stucco decoration.

The geographical extent of the Dvāravatī art style extends beyond the boundaries of the political entity/entities and material culture. However, the boundaries of all three of these phenomena are somewhat ephemeral and not clearly defined or agreed upon. For instance, Dvāravatī style sculpture occurs in peninsular Thailand as far south as the sites of Chaiya, Nakhon Si Thammarat, and Yarang. ${ }^{37}$

To the northeast of the Chao Phraya Basin, Dvāravatī sculpture and motifs have been found at sites such as Mueang Fa Daed (Kalasin province) and Vientiane province of modern-day Laos. ${ }^{38}$ There are variations between these two regions, however. One of the

${ }^{36}$ Brown, The Dvāravatī wheels.

${ }^{37}$ Michel Jacq-Hergoualc'h, The Malay Peninsula: Crossroads of the Maritime Silk Road (100 BC-1300 AD) (Leiden: Brill, 2002); Brown, The Dvāravatī wheels, p. 11; Indrawooth,

'The archaeology', p. 141.

${ }^{38}$ Michel Lorrillard, 'Pre-Angkorian communities in the Middle Mekong Valley (Laos and adjacent areas)', in Revire and Murphy, Before Siam, pp. 186-214. 
most notable is the popularity of carved sema stones (Buddhist boundary markers) on the Khorat Plateau. The carvings of scenes from the Jatakas, the Life of the Buddha, and motifs such as dharmacakras, stupas and stupa-kumbhas that are found on these stones clearly incorporate Dvāravatī style imagery; however, the stones themselves are relatively rare outside of the northeastern region. ${ }^{39}$ In the north of Thailand, Dvāravatī style art has been found at the ancient city of Haripunjaya, modern-day Lamphun (Lamphun province).

The wide geographic distribution of the Dvāravatī art style has in the past resulted in some scholars equating it with the boundaries of a conceived Dvāravatī kingdom or at the very least, Dvāravatī political presence. ${ }^{40}$ However, it seems more likely that the distribution of Dvāravatī art objects represents the spread of artistic and religious ideas. As monks,

Brahmins and artisans travelled throughout the region, they could have carried Buddhism and Brahmanism and subsequently the Dvāravatī art style across political and even cultural boundaries.

Returning to the dating of the Dvāravatī art style, on comparative grounds with India it is hard to argue for it beginning any earlier than the fifth century. At Sarnath during this time a distinctive school of Buddhist sculpture had developed which often depicted the Buddha in a granting boons posture (varada mudra), with diaphanous robes, and body depicted in a flexed posture. ${ }^{41}$ We see this form transmitted to Dvāravatī in a number of surviving examples found in Thailand. ${ }^{42}$ Art historians have generally dated the Dvāravatī

${ }^{39}$ Murphy, 'Buddhism and its relationship to Dvāravatī’, pp. 300-326.

${ }^{40}$ See for example, Prince Damrong Rajanubhab, Tamnan phraphuttha chedi; Quaritch Wales, Dvāravatī.

${ }^{41}$ Guy, Lost kingdoms, cat. nos. 9 and 10.

${ }^{42}$ See for example, Woodward, Sacred sculpture, figs. 38 and 39; Guy, Lost Kingdoms, cat. no. 9 . 
pieces to the sixth or seventh centuries onwards due to stylistic features such as the use of incised lines to indicate the Buddha's garments and also considerations such as the time it would take for the art style to spread from one region to another. ${ }^{43}$ Pala influence from Bengal is also detectable in certain Dvāravatī pieces and thus represents a 'middle phase' in the art form's evolution with these examples dating to the eighth century. ${ }^{44} \mathrm{~A}$ late phase is detectable by Khmer influence and dates from $c$. ninth to tenth centuries.

A review of the surviving epigraphic evidence concurs with a sixth to tenth century date range for a Dvāravatī period, with the majority of inscriptions attributed to the eighth to ninth centuries. ${ }^{45}$ They can be found on a variety of objects including clay tablets, cave walls, sema stones, dharmacakras and Buddha images. Revire lists five Buddha images with inscriptions, one dating approximately to the seventh century, three to the seventh to eighth centuries, and one to the eighth to ninth centuries on paleographic grounds. ${ }^{46}$ Given that the two forms of evidence, stylistic and epigraphic, both point to these pieces being no earlier than the sixth century, with the majority falling between the seventh to eighth, it is hard to argue that Dvāravatī art should be dated earlier than this.

There is limited sculptural evidence from the fifth to sixth centuries, but it is from the south of Thailand, an area not generally associated with Dvāravatī. Furthermore, it is Brahmanical in nature - the earliest known example being a Vishnu image from Chaiya,

${ }^{43}$ Woodward, Sacred sculpture, p. 46; Guy Lost kingdoms, cat. no. 9.

${ }^{44}$ Woodward, Sacred sculpture, pp. 50-52.

${ }^{45}$ See Peter Skilling, 'Traces of the Dharma: Preliminary reports on some Ye Dhammā and Ye Dharmā inscriptions from Mainland Southeast Asia', BEFEO 90-91 (2003-04): 273-87;

Revire, 'Glimpses of Buddhist practices', pp. 249-52.

${ }^{46}$ Ibid. 
Surat Thani province, generally dated to the late fifth to early sixth centuries. ${ }^{47}$ A number of other Vishnus from the region, including a group from Nakhon Si Thammarat, are also dated to the fifth to sixth centuries. ${ }^{48}$ This corpus does at least illustrate that sculpture in the round had arrived in the region by the fifth century. However, unlike Dvāravatī pieces, the earliest examples are still very 'Gupta-esque', showing little sign of indigenous traits. It is only from the seventh century onwards that these Brahmanical sculptures begin to manifest a particularly Southeast Asian aesthetic.

Inscriptional evidence and stylistic dating make it very difficult to push the date of the Dvāravatī art style back before the sixth century. However, archaeological evidence now discussed does build a case for seeing a proto-Dvāravatī culture starting from at least the fifth century. Thus from this evidence we may begin to argue for a transition period that starts before the physical manifestation of a sculptural and epigraphic tradition.

\section{Archaeological evidence}

Scholarship over the past four decades or so, particularly by Thai archaeologists, has led to the discovery of numerous Dvāravatī sites within the Chao Phraya Basin. Indrawooth for instance records over thirty sites while Gallon lists almost fifty ${ }^{49}$ Karen Mudar's study looks at sixty-three sites based on Supanjaya and Vanasin's survey work ${ }^{50}$ However, at

${ }^{47}$ Paul Lavy, 'Conch-on-hip images in peninsular Thailand and early Vaisnava sculpture in Southeast Asia', in Revire and Murphy, Before Siam, pp. 152-73;

${ }^{48}$ Ibid.

${ }^{49}$ Indrawooth, 'The archaeology', p. 127, fig. 6.7; Gallon, Ideology, identity, p. 80, fig. 3.1.

${ }^{50}$ Karen Mudar, 'How many Dvaravati kingdoms? Locational analysis of first millennium A.D. moated settlements in central Thailand', Journal of Anthropological Archaeology 18, 1 
present many of these sites have not been investigated in great detail. Despite this, the data does reflect the extensiveness of this culture in the region. Eight sites in particular have seen sustained archaeological research (see fig. 5) and are discussed in greater detail below. This allows for a more concise concept of proto-Dvāravatī to be developed.

INSERT <Figure 5. Dvāravatī: Main sites discussed and proposed chronologies

Unlike Barram and Glover's definition which argues that the sculpture and the cultural assemblage of Dvāravatī as a whole be re-dated to earlier centuries (viz. first to fourth CE), my proposed definition of proto-Dvāravatī differs somewhat. I argue that the fully-fledged sculptural tradition cannot be dated earlier than the sixth century. Likewise, the full gamut of Dvāravatī pottery does not seem to appear in the proto-Dvāravatī period. Kendi, in the context of central Thailand for instance, do not appear to be found before the sixth century. Furthermore, in the fourth to fifth centuries some prehistoric forms still persist in the material record. Proto-Dvāravatī, as I define it, is very much a transitional phase out of which develops the Dvāravatī period that follows.

'Proto-Dvāravatī' in this definition also indicates a society at a 'proto-state' level of development, whereas 'Dvāravatî' would represent a 'state-level' society. Most archaeological definitions in this regard revolve around centralised control, particularly in

(1999): 1-28; T. Supajanya and P. Vanasin, The inventory of ancient settlements in Thailand (Bangkok: Toyota Foundation, 1983). 
terms of economic, social and religious activities. ${ }^{51}$ These in turn predicate the existence of specialised officials such as administrators, a religious caste (in this case Buddhist monks and Brahmins) and artisans and craftspeople. Archaeologists attempt to ascertain these characteristics by identifying artefacts in the material record that represent these activities. These can range from pottery distribution, to seals and sealings, public building projects and site-size hierarchies. In terms of Dvāravatî this evidence can been seen in the construction of Buddhist and Brahmanical religious monuments, the sculptural tradition in bronze and stone reached by the sixth to seventh century onwards, common pottery types being distributed throughout central Thailand and the creation of large-scale moated sites. ${ }^{52}$ It is significant that in this region, all of these characteristics begin to appear from the fourth to fifth centuries onwards. The proto-Dvāravatī period, it is argued herein, is also the timeframe where incipient 'proto-states' emerge.

A recently published article by Fiorella Rispoli et al. has established a cultural sequence for the Lopburi region of central Thailand and provides a welcome case study in tracing the rise of social complexity and early states. ${ }^{53}$ Their work indicates that there was an acceleration in the growth of social complexity from the late first millennium BCE. This coincides with the appearance of objects of Indian origin in the material record such as glass,

${ }^{51}$ Gary M. Feinman and Joyce Marcus, Archaic states (Santa Fe: School of American Research Press, 1998); Henry Wright, 'Recent research on the origin of the state', Annual Review of Anthropology 6 (1977): 379-97.

${ }^{52}$ For a fuller discussion of Dvāravatī state formation and a review of the available evidence see Gallon, Ideology, identity, in particular, chap. 4, pp. 118-92.

${ }^{53}$ Fiorella Rispoli, Roberto Ciarla and Vincent C. Pigott, 'Establishing the prehistoric cultural sequence for the Lopburi region, central Thailand,' Journal of World Prehistory 26 (2013): $101-71$. 
carnelian and agate beads, terracotta ear lobe ornaments and 'skin rubbers' ${ }^{54}$ This begins to occur in what the authors classify as Iron Age Period 2 (c.200-500/600 CE). They argue that during this period exposure and interaction with India intensified and the process of localisation consequently increased. Like the sites discussed in more detail below, their research clearly illustrates continuity as opposed to rupture in the cultural development of their study area and that the transitions to early statehood began taking place in the third to sixth centuries.

Coming back to Mudar's study, it looks at moated sites within central Thailand based on Supajanya and Vanasin's surveys. ${ }^{55}$ The latter's work has been highly influential in Dvāravatī studies due to their proposal that the coastline stretched much further inland during the Dvāravatī period. They argued that Dvāravatī moated sites would have been located in close proximity to this ancient shoreline. However, a recent study by Trongjai Hutangkura has illustrated that Supajanya and Vanasin overestimated the height of the mean sea level. ${ }^{56}$ What they argued was the coastline has in fact been shown to be a floodplain. ${ }^{57}$ Despite this, Mudar's work remains valid, as her argument does not depend upon the location of the aforementioned coastline. However, the revisions to its position should be kept in mind while reviewing her work.

\footnotetext{
${ }^{54}$ Ibid.: $149-55$.

55 Supajanya and Vanasin, The inventory of ancient settlements.

56 Trongjai Hutangkura, 'Reconsidering the palaeo-shoreline in the lower central plain of

Thailand', in Revire and Murphy, Before Siam, pp. 32-67.

57 Ibid., p. 63, fig. 17.
} 
By measuring their size and agricultural catchment area, Mudar calculates the approximate population of each site and the amount of food each could produce. ${ }^{58}$ She then looks at which sites have population levels larger than their food production levels. She concludes that sites that could not produce a sufficient surplus would have had to obtain it from elsewhere, most likely through agricultural tribute.

In an attempt to show possible centralised control, from which we could infer the incipient stages of state-level societies, Mudar organises the sites into a settlement hierarchy ${ }^{59}$ At 602 ha, Nakhon Pathom is the only site to fit within the top bracket of what she defines as a 'primary centre'. Two other sites, Suphanburi and Praaksrigacha fall into the second category. Mudar further organises the sites into an administrative hierarchy, with Nakhon Pathom again being the only site to fall within the top bracket, classified as a 'supraregional centre'. ${ }^{60} \mathrm{U}$ Thong falls into the third level as a 'district centre' which tempers arguments that were put forward in the past that it was the capital of a Dvāravatī kingdom. ${ }^{61}$

Mudar's study shows interdependence between the sites of central Thailand during the Dvāravatī period. She argues that in the early stages of the Dvāravatī period there may have been smaller-scale competing polities in the Chao Phraya Basin, but that the archaeological evidence at present is not robust enough to ascertain whether this represented

${ }^{58}$ For a similar study of moated sites in northeast Thailand see Stephen A. Murphy, 'How many monks? Quantitative and demographic archaeological approaches to Buddhism in northeast Thailand and central Laos, 6th-11th centuries CE', in Buddhist dynamics in premodern Southeast Asia, ed. D. Christian Lammerts (Singapore: ISEAS, 2015), pp. 80119.

${ }^{59}$ Mudar, 'How many Dvaravati kingdoms?': 3-9, fig. 2.

${ }^{60}$ Ibid.: 8.

${ }^{61}$ Quaritch Wales, Dvāravatī, pp. 20-21. 
any form of unified control or state-level society. ${ }^{62}$ However, she does argues for the existence of a centralised authority by the end of the Dvāravatī period based around Nakhon Pathom from $c$. the ninth to tenth century onwards. However, political power and influence could have shifted over time, and this may explain both U Thong's apparent prominence in the seventh century and its later decline. ${ }^{63}$

It appears from Mudar's settlement hierarchy analysis that there was no centralised Dvāravatī state before at least the seventh century and probably much later. In terms of state development therefore it seems favourable to envision the fourth to sixth centuries $\mathrm{CE}$ as a proto-Dvāravatī period. While these sites were most likely interacting with each other, they also appear to be developing largely independent of each other. It is only in the seventh century onwards that we begin to see epigraphic references for kings and settlement hierarchies that begin to point towards a more centralised state.

It seems appropriate to start the review of archaeological sites with Chansen for two reasons in particular. One, it represents the first systematic archaeological excavation of a Dvāravatī site. Two, Bronson's attribution of the earlier layers of this site as 'Funan'-related is a key issue in the argument over the dating of the 'proto-Dvāravatī period' and has been called into question. ${ }^{64}$

The site of Chansen, about $30 \mathrm{~km}$ north of Lopburi, was excavated between 1968 and 1969 by a joint team from the National Museum of Thailand and University of Pennsylvania Museum (fig. 1) ${ }^{65}$ Based on the radiocarbon and thermoluminescence dates, Bronson deduced five phases of occupation: phases II, III, and IV (spanning the first to seventh

\footnotetext{
${ }^{62}$ Mudar, 'How many Dvaravati kingdoms?': 23

${ }^{63}$ Quaritch Wales, Dvāravatī, pp. 32-3.

${ }^{64}$ Barram and Glover, 'Re-thinking Dvaravati'.

${ }^{65}$ Bronson, 'Excavations at Chansen' : 317.
} 
centuries) represent a proto-historic period, with fully-fledged state development occurring during the transition between phases IV and V, that is, the seventh century. ${ }^{66} \mathrm{He}$ classified phase III (200-450/500 CE) as 'Funan'-related, and appeared to see it as the initial phase of early state development. In this, Bronson's interpretation falls in line with the conventional dating of the Dvāravatī period to the seventh century onwards. However, as Barram and Glover have argued, the label Funan for the early phases dating to the third to late fifth/early sixth centuries is less than ideal given the fact that the material actually reflects more similarities with Dvāravatī cultural assemblages. However, Bronson did not have the benefit of the data sets that we have available to us today and could not have known that the material he labelled as Funan was more likely that of an incipient Dvāravatī culture.

Chureekamol Onsuwan Eyre's study of hierarchical and heterarchical social systems in the eastern Chao Phraya Valley included Chansen as one of the twenty-five sites she surveyed in an area of 255 ha. ${ }^{67}$ Her research and review of previous surveys in the region indicates that rank size analysis did not indicate the existence of site hierarchy during the period of $200 \mathrm{BCE}-300 \mathrm{CE} .{ }^{68}$ However, by $c$. the fifth century CE her results show a strong trend towards a hierarchical settlement pattern around the site of Chansen indicative of a twolevel hierarchy. ${ }^{69}$ The two-level hierarchy she identifies is clearly indicative of the formative stages of state-level society.

${ }^{66}$ Ibid.

${ }^{67}$ Chureekamol Onsuwan Eyre, 'Social variation and dynamics in Metal Age and protohistoric central Thailand: A regional perspective', Asian Perspectives 49, 1 (2011): 47,

56.

${ }^{68}$ Ibid.: 54.

${ }^{69}$ Ibid.: $63-4$. 
New evidence for a proto-Dvāravatī period has been recently uncovered at excavations at Nakhon Pathom. This site represents one of the largest and most highly developed urban centres during the Dvāravatī period. ${ }^{70}$ It covered an area of roughly 3,700 by 2,000 m (740 ha). Situated on the west bank of the Ta Chin River, it is about $60 \mathrm{~km}$ directly west of modern-day Bangkok. Two large stupas were discovered at the centre of the settlement: the first, known today as Chula Pathon Chedi, was excavated in 1940 by Dupont, while the second, known as Phra Pathon Chedi, has recently been excavated by FAD. ${ }^{71}$ Dupont's expedition also uncovered a further stupa, Wat Phra Men, located approximately 1 $\mathrm{km}$ outside the moat to the southwest.

Extensive remains such as Buddha images, dharmacakras, and Pali and Mon inscriptions have been found at this site. This fact, along with its size and location, have led many to conclude that it was a capital city of the Dvāravatī polity, particularly from the eighth century onwards. ${ }^{72}$ However, after Dupont, no systematic archaeological research was carried out here until 1981, when Indrawooth carried out excavations in Phra Prathon subdistrict. ${ }^{73}$ She unearthed pottery, bronze ornaments, iron tools, spindle whorls and glass beads. With the one radiocarbon date she acquired being inconclusive, she relied instead on

${ }^{70}$ Phasook Indrawooth, 'Un antique royaume urbanisé de Thaïlande', in Baptiste and Zéphir, Dvāravatī, pp. 35-6.

${ }^{71}$ For Chula Pathon Chedi see, Dupont, L'Archéologie; For Phra Pathon Chedi see, Usa Nguanphienphak, 'Fouilles récentes au Phra Pathon Chedi', in Baptiste and Zéphir, Dvāravatī, pp. 145-9.

${ }^{72}$ Indrawooth, 'The archaeology', p. 135.

${ }^{73}$ Phasook Indrawooth, Raingan kankutkon ti tambon Phra Pathon, Amphoe Mueang, Changwat Nakhon Pathom [Report of the excavation at Tambon Phra Prathon, Amphoe Mueang, Changwat Nakhon Pathom] (Bangkok: Silpakorn University, 1983). 
pottery and art historical analysis, concluding that the artefacts dated from the eighth to ninth centuries. $^{74}$

Further excavations were undertaken at the site of Hor-Ek in 2009 by Saritpong Khunsong as part of his doctoral research. ${ }^{75}$ This site is located about $500 \mathrm{~m}$ to the northwest of Phra Pathon Chedi. Khunsong's excavations show it was inhabited from the third to eleventh centuries with some of the pottery in the earlier layers showing similarity with material excavated by Bronson at Chansen. This included some burnished ware similar to Phimai Black and which Bronson had dated to the 'late Funan phase' (500-600 CE). Other pottery types such as a painted potsherd with a sun pattern resembled material excavated in Phum Snay in Cambodia radiocarbon-dated to the fifth century. ${ }^{76}$

Khunsong identifies three phases of occupation. The first dates from around the third to sixth centuries and is contemporary with Bronson's Chansen phase III dated to 250-500 CE. The material record shows similarity with Oc Eo and Angkor Borei in the Mekong Delta of Vietnam and Cambodia respectively. It appears that Nakhon Pathom was part of the maritime trade network active at this period. Based on the material record, Khunsong et al. suggest that this phase should be referred to as 'Pre' or 'Proto-Dvāravatî'. ${ }^{77}$ The second phase

${ }^{74}$ Saritpong Khunsong, Phasook Indrawooth and Surapol Natapintu, 'Excavation of a preDvāravatī site at Hor-Ek in ancient Nakhon Pathom', Journal of the Siam Society 99 (2011): 154.

${ }^{75}$ Khunsong et al., 'Excavation of a pre-Dvāravatī Site'; Saritpong Khunsong, Borannakadi Muang Nakhon Pathom: Kansueksa adit kong son klang laeng thawarawadi [The archaeology of Nakhon Pathom town: A study of the past from the centre of Dvāravatī] (Bangkok: Papermate Thailand, 2014).

${ }^{76}$ Khunsong et al., 'Excavation of a pre-Dvāravatī site', p. 163.

${ }^{77}$ Ibid., p. 168. 
spans the seventh to eighth centuries and conforms to the more conventional date range of the Dvāravatī period. The third phase runs from the eighth to eleventh centuries and reflects a later Dvāravatī phase.

Khunsong's research indicates that Nakhon Pathom was in existence long before the conventionally accepted dates for the Dvāravatī period of the sixth to ninth centuries. The occupation sequence begins from the third century onwards and by the fourth to fifth centuries appears to have trade contacts with Oc Eo and the 'Funan' culture. It seems inappropriate to refer to material dating from the fourth to fifth century as a 'Funan Period', as the ceramic evidence from Nakhon Pathom appears to show that there was trade contact only, not a form of overlordship which was presupposed by earlier scholarship. ${ }^{78}$ Also as Barram and Glover have indicated, since the 1960s considerably more work has been done in Vietnam, and it is clear that the material that both Bronson and Boisselier (see below) refer to as 'Funanese' is in fact much more similar to Dvāravatī material. ${ }^{79}$

U Thong, in Suphanburi province, central Thailand, is another substantial Dvāravatī period moated site and shows considerable evidence for both Buddhist and Brahmanical practices (fig. 1) ${ }^{80}$ It too has been touted as an important Dvāravatī centre or capital, particularly during the seventh century. ${ }^{81}$ Excavations at this site were conducted by Boisselier under FAD's auspices in the 1960s which mainly focused on investigating

${ }^{78}$ Coedès, The Indianized states, pp. 36-7.

${ }^{79}$ Barram and Glover, 'Re-thinking Dvaravati', p. 180.

${ }^{80}$ See Revire, this vol.

${ }^{81}$ George Coedès, 'Nouvelles données épigraphiques sur l'histoire de l'Indochine centrale', Journal Asiatique 249 (1958): 123-42; Indrawooth, 'The archaeology', pp. 127-8; For an overview of Dvāravatī centres in general see Mudar, 'How many Dvaravati kingdoms?': 128. 
stupas. ${ }^{82}$ From 1966 to 1970 systematic excavations were carried out by William Watson and Helmut Loofs which produced five radiocarbon dates. ${ }^{83}$ In 2010, excavations consisting of three test pits were carried out by San Thaiyanonda as part of his Master's thesis for Silpakorn University. ${ }^{84}$

Barram and Glover's reappraisal of Dvāravatī dating focus particularly on Watson and Loofs' excavations due to them obtaining radiocarbon dates. By processing an additional five radiocarbon dates and analysing the pottery types found, Barram and Glover compared them with the material from Chansen. They concluded that pottery, such as those with wave and line decoration, spouted vessels and carinated wares as well as clay lamps, are all indicative of Dvāravatī period wares. These artefacts begin to appear in layers datable to the first through fourth centuries. ${ }^{85}$

Thaiyanonda's 2010 excavations of three test pits add additional data to the chronological sequence at $\mathrm{U}$ Thong. In test pit 1 on the rampart of the moat he too uncovered pottery sherds with wavy line decoration. By comparison with excavated examples recovered from the Pontian River in Pahang, Malaysia, and Go-Hang and Canh Den in Vietnam, he

82 Jean Boisselier, 'U-T'ong et son importance pour l'histoire de la Thaïlande', Silpakorn Journal 9, 1 (1965): 27-30; Jean Boisselier, Nouvelles connaissances archéologiques de la ville d'U-T'ong (Bangkok: n.p., 1968).

${ }^{83}$ H.E. Loofs, 'Problems of continuity between the pre-Buddhist and Buddhist periods in Central Thailand, with special reference to U-Thong', in Smith and Watson, Early South East Asia, pp. 342-51.

${ }^{84}$ San Thaiyanonda, 'Kansueksalamdap patthana kan watthanatham thang borannakadi mueang U Thong' [Cultural development of ancient communities at Mueang U-Thong],

(M.A. thesis, Silpakorn University, 2011).

${ }^{85}$ Barram and Glover, 'Re-thinking Dvaravati', p. 180 and table 1. 
dates it to the fourth to fifth centuries ${ }^{86}$ Furthermore, a potsherd with a Pallava inscription appears to date to the mid-sixth century and gives clear indication of Indic influence at the site by this period. Test pits 2 and 3 produced evidence of occupation from the more conventional date ranges of the seventh to ninth centuries. There was also evidence of a late Dvāravatī phase of the ninth to eleventh centuries. Thaiyanonda concludes that both the moat and connections with Indic culture date to at least the mid-fourth century CE. Gallon has argued that moat construction was one means of public works instigated by more centralised authorities and is an indicator for early state development. ${ }^{87}$ That it appears during the fourth century at U Thong lends weight to the argument that we are seeing 'proto-state' level activity during the proto-Dvāravatī period.

INSERT < Figure 6: Fragmentary terracotta relief moulding of three Buddhist monks with alms bowls, today housed in the U Thong National Museum (photograph by Stephen A. Murphy).>

A final, tantalising piece of possible evidence comes in the form of a fragmentary terracotta relief moulding of three Buddhist monks with alms bowls, today housed in the $\mathrm{U}$ Thong National Museum (fig. 6). Stylistically it has been dated to the Nagarjunakonda school of sculpture. This would give it a date range of third to fourth century CE. ${ }^{88}$ It most likely formed part of the façade of a stupa, and has led a number of scholars to conclude that the

\footnotetext{
${ }^{86}$ Thaiyanonda, 'Cultural development', p. 102, fig. 43.

${ }^{87}$ Gallon, Ideology, identity, p. 18.

${ }^{88}$ Some scholars, however, argue for a 7 th-8th century CE date; for example, Revire,

'Glimpses of Buddhist practices', fig. 1.
} 
associated monument must also date to the third to fourth century. ${ }^{89}$ This would place Buddhism arriving at U Thong some two to three hundred years before the 'official' start date of the Dvāravatī period. It would also put it more in line with the arrival of Buddhism at the Pyu sites in Myanmar (see Stargardt, this vol.). However, while both Boisselier and Indrawooth suggest Buddhism may have been present from the third century onwards, neither seemed to consider the ramifications of this in terms of the classification of the Dvāravatî period.$^{90}$ However, as Gallon points out, the age of the monument in question needs to be ascertained by absolute dating methods before any firm conclusions can be reached. ${ }^{91}$ Even so, this fragment does add to a growing body of evidence for reconsidering the date ranges for the early arrival of Buddhism.

Barram and Glover's reappraisal of Watson and Loofs' excavations indicate that U Thong was occupied as early as the first century CE with evidence for Dvāravatī type pottery dating to between the first and fourth centuries. Thaiyanonda's excavations indicate Dvāravatī-style pottery and Indic influence from the fourth century onwards.

The lack of systematic excavations at Dvāravatī period sites has been further addressed recently by Gallon's doctoral research at the moated site of Kamphaeng Saen (fig. 1). ${ }^{92}$ His dissertation sets out to gain a better understanding of urbanisation during the Dvāravatī period using the site of Kamphaeng Saen as a case study. Situated roughly equidistant between Nakhon Pathom and U Thong, it represents a smaller-scale site and may

${ }^{89}$ Boisselier, 'U-T’ong et son Importance', pp. 27-30; Indrawooth, 'The archaeology', p. 138.

${ }^{90}$ Boisselier, 'U-T'ong et son Importance', pp. 27-30; Indrawooth, 'The archaeology', p. 138.

${ }^{91}$ Gallon, 'Ideology, identity’, p. 75.

${ }^{92}$ Ibid. 
have functioned as a satellite settlement of its two larger neighbours. As with its larger counterparts it has clear evidence for the adoption of Buddhism. The discovery of a dharmacakra and its inscribed socle $\mathrm{e}^{93}$ as well as three Buddha images are indicative of this. ${ }^{94}$ Of most significance to this discussion are the results of eight AMS radiocarbon dates obtained from controlled excavations which Gallon undertook in 2009 and $2010 .{ }^{95}$ They indicate that the site was occupied from the early fifth century and declined a few centuries later. The most intensive phase of occupation was from the fifth-sixth centuries to the midseventh century, with the site being abandoned by the ninth century. ${ }^{96}$

Gallon's research has cast new light on the debate regarding the Dvāravatī period. He points out that material culture from the stratigraphic layers dating to the fifth to sixth centuries has Dvāravatī-style ceramics, saddle querns and beads, but is also missing a number of other markers of Dvāravatī culture such as earthenware with stamped impressions as well as blue-green glazed Persian wares. ${ }^{97} \mathrm{He}$ therefore prefers the labels 'Early Dvāravatî̀' or 'Proto-Dvāravatî’' for the fifth to sixth century layers. Based on stylistic dating, he also notes that it is only in the seventh to eighth centuries that we see significant investment in Buddhist art and architecture at the site. ${ }^{98}$ This latter observation highlights the point stressed

${ }^{93}$ The socle is the part that connects the pillar (stambha) and wheel (cakra) securely in place.

${ }^{94}$ Gallon, 'Ideology, identity', pp. 332-5.

${ }^{95}$ Ibid., p. 275, table 5.5.

${ }^{96}$ Ibid., p. 283.

${ }^{97}$ Ibid., p. 284.

${ }^{98}$ Ibid., pp. 285-6. Gallon's dissertation also contains two useful tables (A.1 and A.2) summarising all known radiocarbon and thermoluminescence dates from Dvāravatī sites as of 2013. 
throughout this article that the characteristic art and architecture of Dvāravatī only becomes visible in the archaeological record from the sixth to seventh centuries onwards.

At two sites excavated over the past ten years, Phromtin Tai and Kheedkhin, further evidence has emerged for continuity between late prehistory and the Dvāravatī period (fig. 1). However, in both cases a well-defined proto-Dvāravatī period was not clearly identified.

The moated site of Phromtin Tai about $20 \mathrm{~km}$ northeast of Lopburi town has been subject to archaeological investigations led by Thanik Lertcharnrit from 2004 to 2013 with future seasons planned. ${ }^{99}$ The site shows evidence for occupation from the Bronze Age through to the Dvāravatī period. Lertcharnrit has interpreted these levels through a combination of radiocarbon dating and analysis of the cultural material discovered. $\mathrm{He}$ identifies a clear Dvāravatī occupation layer from the sixth to ninth centuries. He also took five radiocarbon dates from the Iron Age layer, however the calibrated date ranges vary widely. ${ }^{100} \mathrm{He}$ assigns the Iron Age layer to $500 \mathrm{BCE}-500 \mathrm{CE}$ and states categorically that there was no break in occupation between this layer and that of Dvāravatī. ${ }^{101}$

About $40 \mathrm{~km}$ to the south in Saraburi province lies the site of Kheedkhin. It is a smallscale Dvāravatī site of only approximately 620 by $620 \mathrm{~m}$. Notable finds include the usual pottery assemblage of carinated, spouted and stamped ware as well as a terracotta lion image and a fragment of a dwarf (gana) image. ${ }^{102}$ Excavations undertaken at the site between 2007

\footnotetext{
${ }^{99}$ Thanik Lertcharnrit, 'Phromthin Tai: An archaeological perspective on its societal transitions', in Revire and Murphy, Before Siam, pp. 120-21.

${ }^{100}$ Ibid., table. 1.

${ }^{101}$ Ibid., p. 123.

${ }^{102}$ Saritpong Khunsong, 'Archaeological excavation at Kishkindha, a Dvaravati city in central Thailand', in Unearthing Southeast Asia's past: Selected papers from the 12th
} 
and 2008 by Silpakorn University revealed evidence for Iron Age occupation from $c .500$ BCE onwards. Radiocarbon dates obtained from the excavation give some indication of dating. However, there are wide ranges in dates, sometimes as large as \pm 690 years. ${ }^{103}$

Khunsong therefore primarily used relative dating techniques to establish the chronology. ${ }^{104}$ He divides the occupation into two ranges, the prehistoric period from between 2500-1600 Before Present (BP) (550 BCE-350 CE) and the Dvāravatī period dating between 1400-1200 BP (550-750 CE) or the sixth to eighth centuries. ${ }^{105}$ This appears problematic as according to these dates there is a gap of two hundred years between the late prehistoric period and the Dvāravatī period which goes unexplained in the article. However, from the Thai language site report it is clear that there is continuity at the site and that these above date ranges indicate the timeframes which can be clearly bracketed. The individual stratigraphy of the test trenches show that there is continuity between layers ${ }^{106}$ and it appears

International Conference of the European Association of Southeast Asian Archaeologist, vol. 1, ed. Marijke J. Klokke and Véronique Degroot (Singapore: NUS Press, 2013), pp. 234-40. ${ }^{103}$ Ibid., tables 1 and 2.

${ }^{104}$ Ibid.; see also Fine Arts Department of Thailand, Raignanchapapsombon khrong kansueksa wichai lae patthana mueang Kheedkhin tambon Ban Ho amphoe Ban Ho changwat Saraburi [Final report of the study and development of Kheed Khin, tambon Ban Ho amphoe Ban Ho changwat Saraburi] (Ayutthaya: FAD Regional Office no. 3, 2007), p. 203.

${ }^{105}$ Khunsong states that $1400-1200$ BP equates to the seventh to ninth centuries, but it appears he has miscalculated the conversion of BP to CE. BP dates are calculated from 1 Jan. 1950 as opposed to the current Gregorian calendar year, as Khunsong has appeared to have done.

${ }^{106}$ See, FAD, Raignanchapapsombon, figs. 3.10, p. 40, and 3.23, p. 62. 
more a case that the excavators were unable to clearly establish a relative or absolute dating for the two-hundred-year gap $c .350-550 \mathrm{CE}$ with the diagnostic finds available to them. Furthermore, they state that the material record from test trenches excavated in the ramparts shows that the site was occupied, or at least in use, in late prehistory before the moat was built and continued to be occupied in the Dvāravatī period. ${ }^{107}$

At both Kheedkhin and Phromtin Tai there is clear evidence for habitation from late prehistory into the Dvāravatī period from the sixth century onwards. While the material record and dating techniques at both sites did not allow for a more refined dating of the sequence of the site, neither show any signs of abandonment and appear to have transitioned from late-prehistory to Dvāravatī somewhere in the fourth to fifth centuries. It seems that there was a proto-Dvāravatī phase at these sites, but it is not clearly detectable in the stratigraphy.

Turning to the northeast, the two largest sites in the region, Mueang Sema and Mueang Fa Daet, also show evidence for proto-Dvāravatī phases (fig. 1). Mueang Sema, located on the Lam Ta Khong River, part of the Mun River system, is in Sung Noen district, Nakhon Ratchasima province. ${ }^{108}$ It covers an area of over $150 \mathrm{ha}^{109}$ and has been divided into three phases of occupation. ${ }^{110}$ The earliest phase dates from the fourth to fifth centuries and

${ }^{107}$ Ibid., pp. 59-61, 204-7.

${ }^{108}$ See also Higham and Evans et al., this vol. Both articles discuss the Mun Valley region in northeast Thailand and also argue for transitions taking place in the fourth to sixth centuries.

${ }^{109}$ Elizabeth Moore, Moated sites in early North East Thailand, British Archaeological Reports (BAR) International Series 400 (Oxford: British Archaeological Reports, 1988), p. 9.

${ }^{110}$ Khemica Wangsuk, Patthanakan thang watthanatham nai lom mae nam mun:

Koranisueksa laeng borannakadi Mueang Sema amphoe Sung Noen changwat Nakhon

Ratchasima [The cultural development in the Mun River Basin: A case study of the 
has been classified as late prehistoric by the excavator. ${ }^{111}$ The second phase dates from the sixth to ninth centuries and has been classified as Dvāravatī period owing to the pottery record and clear evidence for Buddhism during this time. The third phase, from the ninth to twelfth centuries, shows evidence of growing Khmer influence as indicated by the presence of Buriram ceramics and Song Dynasty ware.

These three phases fall neatly into the normal parameters of the established Thai dating system. However, a closer look at this chronology and the material record indicates that it is not as clear-cut as it seems. For instance, one particular group of ridge pottery found in the earliest stratigraphic layers (fourth-fifth century) is also found in layers III and IV at Chansen. ${ }^{12}$ Furthermore, Khemica Wangsuk points out that this pottery type is also found in the second phase and evolves into a pottery type that is commonly used in the Dvāravatī period of the sixth to ninth centuries. Another group of earthenware has also been found in the layers representing phase 1 and are common to the Pasak region of Thailand. They were also recorded at Chansen in layer IV, which dated to between the mid-fourth to sixth centuries. ${ }^{113}$

Analysis of the pottery record between phases one and two at Mueang Sema shows there is clear continuity between them. This along with comparisons with Chansen indicate that it is more appropriate to refer to the fourth to fifth century phase at Mueang Sema as proto-Dvāravatī. When we also consider that there is no evidence for early phases of

archaeological site at Muang Sema Sung Noen district, Nakhon Ratchasima province] (M.A. thesis, Silpakorn University, 2000), p. iv.

${ }^{111}$ Ibid., p. iv.

${ }^{112}$ Ibid., p. 118.

${ }^{113}$ Ibid.; Bronson, 'Excavations at Chansen', pp. 359-63. 
prehistory in the stratigraphic sequence at the site, the term late-prehistory also appears to be an inappropriate designation at this site.

The largest moated site in the Khorat Plateau is Mueang Fa Daed in Kalasin province. Measuring about 170 ha in total, it also has the most substantial evidence of Buddhist material remains in the region. ${ }^{114}$ Excavations carried out at the site in 1991 by Silpakorn University revealed a continuous occupation sequence stretching back into the late prehistoric period, c.300 BCE. ${ }^{115}$ This was followed by what the excavation reports refer to as a protohistoric period. Based on radiocarbon dates and the pottery record, it spanned around the second to sixth centuries CE. After this we have a historic period which dates from the seventh to eleventh century and is associated with Dvāravatī culture. At this site the excavators have chosen to deviate from the standard periodisation. By recognising a protohistoric period they add weight to the argument that the fourth to sixth centuries were a transition phase between late prehistoric and historical (viz. Dvāravatī) societies.

\section{Discussion}

The brief review of archaeological sites above indicates that by the fourth to fifth centuries they begin to show characteristics that are best described as proto-Dvāravatī. The change in terminology proposed here is done to indicate two main factors. One, that there is in all the cases studied, continuity between the fourth and fifth centuries and that of the sixth to seventh centuries onwards. Second, the term proto-Dvāravatī reflects a period in which society is undergoing significant increases in socio-political complexity associated with the

\footnotetext{
${ }^{114}$ Murphy, 'The distribution of sema stones', p. 223.

${ }^{115}$ Phasook Indrawooth, Raingan kankutkon Mueang Fa Daet Song Yang Ampoe Kamalasai Changwat Kalasin [Report on the excavation at Muang Fa Daed Song Yang, Kamalasai district, Kalasin province] (Bangkok: Silpakorn University, 2001), p. 74.
}

Commented [A1]: which spelling would you prefer to use? (both Mueang Fa Daed and MF Daet appear.

Commented [A2]: Lets go with this (Mueang Fa Daed), it is the more common form. 
arrival of organised religions such as Buddhism and Brahmanism. These changes are indicative of proto-state level society where a central authority begins to extend its control over a settlement and surrounding smaller-scale sites. This is illustrated in the archaeological record by the construction of religious buildings, the control of resources and trade, and the execution of large public works such as the construction of moats and banks. However, it is not until at least the seventh century that we get indications that these large urban centres are coming under the sway of other comparably powerful centres.

The term late prehistory on the other hand implies kinship-based societies organised around individual centres that do not hold sway over larger territories or non-kinship-based groups. This term, and the lack of a transitional period following it, also suggests that the rise of early states and what we consider 'historic periods' arose almost instantaneously. A protoDvāravatī period on the other hand, provides a space in time within which we can place important transitions. For instance, the accomplished nature of the stone and bronze sculpture of Dvāravatī art could not suddenly have appeared. This level of sophistication would take many years to reach and require the presence of specialist craftspeople and artisans as well as the control of resources such as bronze, wood and stone for it to become viable. Since traditional ideas of Indianisation have been largely discarded, it therefore begs the question as to how this art form arose. Dating the start of the Dvāravatī period to the appearance of such sculpture denies Dvāravatī art and the ateliers necessary to produce it any time to evolve.

The question of how long it takes for Buddhism to manifest itself in the material record is also a pertinent one. It may have been present for some time before leaving any detectable record. A similar argument can also be made for the appearance of Dvāravatī as an historical entity. Historians tend to date this to the seventh century based on evidence in the Chinese sources. However, the arrival of a Dvāravatī embassy at the Tang court is not the start of this polity's existence, but instead its first known instance of being officially 
recognised. The Dvāravatī polity must therefore have already been in existence for some time to be able to reach a level of self-awareness where it wished to define and delineate itself visà-vis the Tang court and by extension, its immediate neighbours. Also, it must have also reached a certain level of economic and political power in order to mount such an expedition. As with Dvāravatī art and Buddhist religion, the Dvāravatī polity is a result of long processes that unfortunately are not always clear to us in the archaeological, art historical and historical records that survive today.

Buddhism appears to have been present to some degree in the area of central Thailand by at least the fourth to fifth centuries onwards and perhaps earlier. However, at first it must have only been operating on a small scale and may not have received large levels of donations. Without this, it could not produce monumental architecture or sculpture. The first manifestations of these two material forms were most likely in wood. ${ }^{116}$ Wooden architecture and sculpture is much less resource intensive to produce and would have also been a familiar medium to the local populations. A few surviving examples of wooden Buddha images from the Mekong Delta of Vietnam dating from the third to sixth centuries point to the existence of this tradition in this region at least. ${ }^{117}$ Unfortunately, wood is a perishable medium,

\footnotetext{
${ }^{116}$ Depictions of wooden structures are present on a number of 7th-9th century CE sema stones from northeast Thailand and give some indication of what this architectural form may have looked like. See Stephen A. Murphy, 'Sema stones in Lower Myanmar and Northeast Thailand: A comparison', in Revire and Murphy, Before Siam, pp. 352-71.

${ }^{117}$ See John N. Miksic, 'Introduction. The beginning of trade in ancient Southeast Asia: The role of Oc Eo and the Lower Mekong River', in Art and archaeology of Funan: Pre-Khmer Kingdom of the Lower Mekong Valley, ed. James C.M. Khoo (Bangkok: Orchid, 2003), fig. 1-11; Vo Si Khai, 'The kingdom of Fu Nan and the culture of Oc Eo', in Khoo, ibid., fig. II-
} 
particularly in tropical Southeast Asian climates. Therefore, we have no record of Buddhist sculpture before the sixth to seventh century in central Thailand, though we can posit that it must have existed before these dates.

As Buddhism took hold and developed it would have been able to attract more wealthy donors, particularly the elite and ruling classes. In tandem with this the Dvāravatī polity or polities must have also been growing in power and size. More resources would have begun to become available and the tradition of stone and bronze sculpture presumably developed. It is difficult to establish how long this process took. However, as the pottery record in general emphasises continuity between the fourth to fifth centuries with that of the sixth to seventh centuries onwards, it appears that this process was taking place within this timeframe.

Barram and Glover also made comparisons with other regions in an attempt to strengthen their argument. They point out that in many of the societies neighbouring the Dvāravatī, evidence now coming to light shows that Indian religions and early 'state' development was under way by the fourth to fifth centuries. They therefore query why in Thailand this process supposedly did not begin until two centuries later, in the sixth to seventh centuries. As a number of other articles in this volume deal with these questions, in Myanmar and Cambodia in particular, I will not discuss them in any detail here. Suffice to say that in Myanmar urbanisation and the evidence for Buddhist art and architecture is clearly present by the fourth to fifth centuries. Pre-Angkorean Cambodia also shows evidence for urbanisation and early states from the fourth to fifth centuries. ${ }^{118}$ However, as with the Dvāravatī polities, monumental art and architecture in Cambodia did not really get under way

8; Nancy Tingley and Andreas Reinecke, eds. Arts of ancient Viet Nam: From river plain to open sea (Houston: Museum of Fine Arts, 2009), cat. no. 27.

${ }^{118}$ Stark, 'Pre-Angkorian and Angkorian Cambodia', pp. 96-100; see also, Heng, this vol. 
until the sixth to seventh centuries. The earliest temples at the site of Sambor Prei Kuk, for instance, date from around the seventh century, ${ }^{119}$ while the imposing Vishnu imagery from Phnom Da also dates to the seventh to eighth centuries. Here we see parallels with the development of Dvāravatī art in that while early 'state development' seems to begin in the fourth or fifth centuries, it takes about two hundred years for Pre-Angkorean art and architecture to blossom into a fully-fledged tradition.

Evidence for peninsular Thailand discussed above also shows Brahmanical imagery in existence from about the fifth to sixth century onwards. In sum, with more comparative evidence now becoming available from surrounding regions, it is hard to imagine that for some reason central Thailand would have been lagging approximately two hundred years behind.

\section{Conclusion}

Barram and Glover's challenge to the conventional dating of the Dvāravatī period has forced scholars to reassess their assumptions. The brief overview of archaeological sites and survey work carried out in this article clearly shows that there is a strong case for postulating a proto-Dvāravatī period spanning the fourth to fifth centuries. However, unlike Barram and Glover, who argue that the sculptural and the cultural assemblage of Dvāravatī as a whole be re-dated to earlier centuries, I have endeavoured to illustrate continuity with the past.

Considering the fourth to fifth centuries as a proto-Dvāravatī period allows for the postulation of a timeframe within which the Dvāravatī polity and its associated forms of Buddhist, and to a lesser extent Brahmanical, art and architecture emerged. It implies continuity between these centuries and those following it, and indicates that what we see today in terms of Dvāravatī

\footnotetext{
${ }^{119}$ Ichita Shimoda and Sae Shimamoto, 'Spatial and chronological sketch of the ancient city of Sambor Prei Kuk', Aséanie 30 (2012): 12-74.
} 
art and architecture were the products of longer processes. These may not be explicitly clear to us at present, but by redefining this transitional phase as a proto-Dvāravatī period, it is hoped that this will in turn encourage scholars to refocus their research on this issue. 